\title{
Žákovské hodnocení výuky na gymnáziu: výpovědi sexty $A$
}

\author{
Ingrid Čejková \\ Masarykova univerzita, Filozofická fakulta, Ústav pedagogických věd \\ Redakci zasláno 30. 3. 2018 / upravená verze obdržena 11. 8. 2018 / \\ / k uveřejnění přijato 25. 8. 2018
}

\begin{abstract}
Abstrakt: Cílem předloženého textu je prostřednictvím kvalitativního výzkumného šetření zjistit, jak žáci gymnázia hodnotí výuku jednotlivých vyučovacích předmětů, a také načrtnout, zda žákovské hodnocení výuky může disponovat hybnou silou umožňující žákům ovlivňovat podobu výuky směrem k vyšší efektivitě a kvalitě. Tato problematika byla zkoumána za pomoci zúčastněného pozorování výuky a rozhovorů se žáky a vyučujícími jedné středoškolské tř́ídy. Na základě analýzy získaných dat bylo zjištěno, že žáci jsou schopni hodnotit výuku z různých úhlů pohledu a brát při tom v potaz celou řadu prvků. Stěžejními prvky výuky, které žáci sledují, jsou např́klad vlastnosti a jednání učitele, expertnost učitele, didaktické kompetence učitele a s tím související cíle, metody, efekty výuky atd. Žákovské hodnocení výuky je tedy výsledkem rozsáhlé analýzy jednotlivých prvků výuky a jejich opětovné syntézy, která ústí ve formulování finálního stanoviska.
\end{abstract}

Klíčová slova: víceleté gymnázium, hodnocení výuky, efektivita výuky, kvalita výuky, hlas žáků, situační mapy, matematika, český jazyk a literatura

\section{Teoretická východiska}

Hodnocení je proces posuzování a přiřazování pozitivního či negativního významu a hodnoty různým jevům za účelem jejich komparace. Výuka bývá procesu hodnocení vystavena většinou zcela přirozeně a je posuzována optikou celé řady aktérů od vyučujících přes žáky a rodiče až po externí hodnotitele. Systematicky se hodnocením výuky zabývá pedagogický výzkum, přičemž v této souvislosti výzkumníci často využívají pojmů efektivita výuky a kvalita výuky. Efektivitou rozumíme účinnost, komplexní výsledek nebo také měřítko, které znázorňuje poměr mezi vynaloženými prostředky a výsledkem nebo mezi skutečným a možným výsledkem (srov. Starý \& Chvál, 2009). Efektivitu ve vzdělávání nejčastěji spojujeme se vzdělávacími výsledky žáků, které můžeme považovat za více méně objektivní ukazatel efektivity výuky. 
Při žákovském hodnocení výuky můžeme sledovat také žáky subjektivně vnímanou efektivitu výuky, která se může pojit např́́klad se žáky vnímanou užitečností či využitelností učiva. Kvalitou rozumíme vlastnosti či charakteristiky konkrétní výuky, které ji odlišují od výuky jiné a které je možno zkoumat a srovnávat např́íklad v závislosti na standardu nebo ideálu (srov. Starý \& Chvál, 2009). Žáci (jakož i další aktéři života ve škole) tak mohou hodnotit výuku na základě jejích výsledků, což směřuje právě k efektivitě výuky a na základě procesů, které se ve výuce odehrávají a kterými lze výuku charakterizovat a popsat, což směřuje právě ke kvalitě výuky (srov. Janík et al., 2013). Níže jsou v krátkosti představeny některé koncepty vztahující se k efektivitě a kvalitě výuky, které jsou klíčové pro tento text.

Známe řadu faktorů ovlivňujících efektivitu výuky, které se v zásadě dají rozčlenit do dvou skupin. První skupinu faktorů můžeme hledat v charakteristikách žáka a jeho rodiny, které můžeme považovat za jakousi startovní čáru žáka. Jde například o socioekonomický status rodiny, vzdělání rodičů a podobně. Druhou skupinu faktorů nalezneme ve škole, a zejména pak u učitele a jeho pojetí vyučování, práce se žáky a podobně (srov. Starý et al., 2012). Otázkou je, jakou část efektivity výuky lze vysvětlit působením charakteristik žáka a jeho rodiny a jakou část lze vysvětlit působením školy a učitele. Hattie (2003) tvrdí, že situace je z padesáti procent nakloněna na stranu charakteristik samotného žáka, ze třiceti procent pak efektivitu výuky může ovlivnit učitel, po pěti procentech je připsán vliv působení rodiny, spolužáků, prostředí a podmínek školy a ředitele. Učitel je tedy svým působením do značné míry schopen ovlivnit efektivitu výuky. Takovému pojetí výzkumu efektivity výuky ř́káme „proces-produkt“, kdy procesem je vyučování a produktem jsou zejména vzdělávací výsledky žáka. $Z$ toho důvodu se řada výzkumníků zaměřuje na charakteristiky výuky z pohledu činnosti, schopností a dovedností učitele, které se promítají do vyučování (více viz Janík et al., 2013). Například Mortimore a kol. (1989) považují za klíčové faktory efektivní výuky: jasnou strukturu, přítomnost intelektuální výzvy, výukové prostředí orientované na práci, maximum komunikace ve třídě a pozitivní sociální klima třídy a školy. Dále Scheerens (2004) označuje jako klíčové faktory efektivní výuky: jasnost výkladu, flexibilitu učitele v používání metod a forem výuky, entuziasmus učitele, podněcující a důsledný př́stup učitele, přiměřený kriticismus, povzbudivé působení učitele na žáky, seznamování žáků s kritérii hodnocení, stimulaci myšlení a učení žáků a aktivní interakci se žáky. V tomto pojetí je tedy učitel klíčovým aktérem, který má výrazný vliv na efektivitu výuky, což již pozvolna předznamenává některé výsledky tohoto výzkumu. 
Nahlédněme nyní v krátkosti také na některé koncepty vztahující se ke kvalitě výuky. Harvey a Green (1993) formulovali různá pojetí kvality výuky, a to kvalitu jako výjimečnost, bezchybnost, účelnost, adekvátní protihodnotu nebo transformaci. Tato pojetí tak mohou znázorňovat širší optiku, skrze kterou lze na kvalitu výuky nahlížet $\mathrm{z}$ různých úhlů pohledu. Při výzkumu kvality výuky se však častěji pracuje s konkrétními kategoriemi a komponentami výuky. V českém prostředí Janík a kol. (2013) identifikovali tyto komponenty kvalitní výuky: jasná organizace a řízení třídy, strukturované a jasné zprostředkování cílů a obsahu vzdělávání, učební úlohy podněcující kognitivní aktivizaci žáků a podpůrné učební klima. Zmíněné komponenty výuky směřují k poměrně pevnému vedení výuky, které je však zaměřeno na žáka a jeho učení. Kvalita výuky je ve školství často diskutovaným a stále aktuálním tématem, například i Česká školní inspekce v roce 2016 představila model kvalitní školy, který je složen ze šesti oblastí, přičemž jednou z nich je i oblast výuky. ${ }^{1}$ Autoři modelu kvalitní školy mimo jiné doporučují, aby učitelé připravovali výuku v souladu s cíli definovanými v kurikulu a potřebami žáků. K tomu mají učitelé využívat široké spektrum výchovných a vzdělávacích strategií, ve kterých se zaměří jak na cíle akademické, tak na cíle $\mathrm{v}$ rámci osobnostněsociálního rozvoje žáků. Dále mají učitelé systematicky sledovat vzdělávací pokrok každého žáka. Smyslem tohoto počínání je implementace takových principů výuky, které maximálně přizpůsobují volbu výukových cílů, prostředků a metod schopnostem žáků a vedou k jejich harmonickému rozvoji (srov. Chvál, 2018). Zásadním předpokladem pro realizaci kvalitní výuky dle tohoto modelu je přesvědčení učitele o možnosti rozvoje každého žáka bez ohledu na jeho aktuální pozici na cestě ke vzdělávacím cílům. Z textu výše je zřetelná orientace výuky na žáka a také apel na individualizaci výuky.

Známe nepřeberné množství rozličných kritérií, pojetí, dimenzí a faktorů efektivní a kvalitní výuky, které mají svůj základ v hodnocení výuky různými aktéry. Avšak obvykle absentuje hodnocení, které staví na výrocích samotných žáků, tedy přímých účastníků výuky. Toto téma se v našem prostředí zkoumá spíše optikou obliby vyučovacího předmětu nebo postoje žáků k vyučovacímu předmětu (např. Federičová \& Münnich, 2015; Chvál, 2013; Kubiatko, Mrázková, \& Janko, 2011; Pavelková, 2013). ${ }^{2}$ S tématem žákovského

Dalšími jsou: koncepce a rámec školy, pedagogické vedení školy, kvalita pedagogického sboru, vzdělávací výsledky žáků a podpora žáků při vzdělávání.

2 Postojům žáků ke škole se věnuje také testování PISA, avšak Straková (2010) tvrdí, že tyto informace jsou př́liš kusé a nelze z nich vyvozovat koncepční závěry. 
hodnocení výuky se ve výzkumných zprávách setkáváme spíše okrajově a epizodně. I sami žáci, pokud mají možnost sdělovat učitelům své hodnocení různých oblastí života ve škole, se k výuce vyjadřují pouze okrajově a nepříliš často (Vidláková, 2011). Z těchto důvodů se tento text zaměří právě na problematiku žákovského hodnocení výuky, které je v tomto textu metaforicky označováno jako hlas žákủ. Jde o žákovskou komunikační aktivitu směřující $\mathrm{k}$ učiteli, při které žáci podávají zpětnou vazbu na výuku a vyjadřují přání s výukou spojená (srov. Cook-Sather, 2006; Rudduck \& McIntyre, 2007), přičemž se předpokládá, že žáci budou vyslyšeni a obsah jejich promluv bude naplněn (Cook-Sather, 2006; Fletcher, 2007). Hlas žáků je tedy možností, jak mohou žáci činit rozhodnutí vztahující se k vlastnímu učení a ovlivnit tak podobu výuky (Cook-Sather, 2006; Harper, 2000; Rogers, 2005). V hlase žáků tak nejde o pouhé vyjádření žákovského hodnocení výuky, ale také se jedná o prŕležitost ke změně výuky. Winograd (2002) tvrdí, že učitelé i žáci jsou si vědomi toho, že disponují tím, po čem druhá strana touží, a v důsledku toho mohou ovlivnit podobu výuky. Cothranová a Ennisová (1997) tento stav popisují jako směnný obchod, na jehož základě lze vyjednávat. Žáci například vědí, že učitelé chtějí, aby ve výuce spolupracovali, na druhou stranu učitelé vědí, že žáci chtějí dobré známky. Hargreaves (1972) v této souvislosti hovoří o pseudoshodě či pracovním konsensu, který má tři základní podoby. Jde o kompromis, kdy učitelé i žáci sleví ze svých požadavků a cílů; hegemonii, kdy učitel prosazuje své cíle a žáci se podřizují; a kontrahegemonii, kdy cíle prosazují žáci a přizpůsobují se učitelé.

Zdá se, že o hodnocení, efektivitě a kvalitě výuky toho již víme mnohé. Na druhou stranu řada výzkumů byla realizována skrze kvantitativní optiku (srov. Janíková et al., 2009). Doposud tak víme poměrně málo o tom, jak sami žáci spontánně hodnotí výuku a jaké argumenty při svém hodnocení předkládají. Značná část výzkumů v našem prostředí také byla realizována na základních školách, absentuje tak pohled středoškoláků. ${ }^{3}$

\section{Metodologie}

Cílem tohoto textu je zaplnit výše zmíněná bílá místa a nalézt odpovědi na hlavní výzkumnou otázku: jak žáci gymnázia hodnotí výuku jednotlivých vyučovacích předmětů a také vedlejší výzkumnou otázku: zda žákovské

3 Výjimku tvoří např. studie Žáka (2008), který zkoumá parametry kvality výuky fyziky na gymnáziu. 
hodnocení výuky může disponovat hybnou silou umožňující žákům ovlivňovat výuku směrem $k$ její vyšší efektivitě a kvalitě. Protože je žákovské hodnocení výuky jednotlivých vyučovacích předmětů velmi rozsáhlé, pro účely tohoto textu byl pro ilustraci vybrán žáky nejlépe a nejhůře hodnocený vyučovací předmět (viz tab. 1), a to český jazyk a literatura, vedený učitelem Čapkem, a matematika, vedená učitelem Pythagorem.

Pro průzkum problematiky žákovského hodnocení výuky byl zvolen kvalitativní výzkumný přístup (Creswell, 2014; Řiháček \& Hytych, 2013; Švaříček et al., 2007) s využitím postupů a nástrojů, které nabízí zakotvená teorie (Clarke, 2005; Charmaz, 2006; Strauss \& Corbin, 1999). Participanty výzkumu se po jedno pololetí ${ }^{4}$ stali žáci a vyučující sexty A, kteř́ byli vybráni na základě dostupného výběru. Sexta $A$ je součástí osmiletého gymnázia s kapacitou pět set žáků, které se nachází ve větším městě. Jedná se o všeobecné gymnázium, které se nespecializuje na určitou vzdělávací oblast. Gymnázium není vnitřně diferencováno a sexta A v porovnání s ostatními tř́́dami nevykazuje odlišnosti. Výběr takové školy a žáků umožňuje nahlédnout do života všední školní třídy. Výzkum zde sestával ze vzájemně se prolínajících metod sběru dat, zúčastněného pozorování výuky $(\mathrm{n}=32)$ a hloubkových polostrukturovaných rozhovorů se žáky a učiteli $(n=12)$.

Cílem zúčastněného pozorování výuky bylo zachytit situaci ve třídě, aby bylo možno precizně popsat a dobře pochopit, co se ve výuce odehrává, a přitom nebylo potřeba spoléhat se pouze na zprostředkovaná data. $V$ rámci pozorování výuky byly pořizovány její videonahrávky, které se následně staly předmětem videostudie. Její předností je možnost detailního průzkumu jak řečových aktů, tak i neverbálních projevů, ke kterým je možno stále se vracet. Zvykem je, že jsou videonahrávky převedeny do podoby transkriptu a poté jsou podrobeny analýze (Najvar et al., 2011). V tomto výzkumu však byl analyzován př́mo audiovizuální materiál v programu Atlas.ti prostřednictvím otevřeného kódování (Strauss \& Corbin, 1999). Kódy byly nastaveny jako dvouúrovňové. První úroveň nesla název obecnější induktivně vzniklé kategorie a druhá označovala jemnější členění. ${ }^{5}$ Takto zakódovaná data byla dále podrobena deskriptivní analýze. Účelem analýzy videodat bylo vytvoření charakteristiky výuky.

Výzkum probíhal od poloviny ledna do konce června 2016 ve třídě, kde je 32 žáků: 15 děvčat a 17 chlapců.

5 Pro ilustraci, kódy vypadaly např́íklad takto: metoda výuky: prednáška s otázkami, žáci: zapisují si. 
Zúčastněné pozorování výuky otevřelo dveře hloubkovým polostrukturovaným rozhovorům, které již byly založeny na datech, a staly se tak přesnějšími a kontextově vázanými. Celkem bylo realizováno osm individuálních rozhovorů se žáky (724 minut) a jeden skupinový rozhovor se žáky (45 minut). Předmětem těchto rozhovorů bylo žákovské hodnocení výuky jednotlivých vyučovacích předmětů. Pro individuální rozhovory byli žáci vybráni na základě zhodnocení tří faktorů, které výrazně charakterizují povahu zkoumané školní třídy: míra participace na výukové komunikaci, prŕíslušnost ke kamarádským skupinám a prospěch. Tento způsob výběru sledoval cíl, aby vybraní žáci dobře reprezentovali názory různých žákovských skupin, které se ve tř́́dě vyskytují. Žáci byli oslovováni postupně, tedy vždy na základě rozhovoru předchozího byl vybrán žák pro rozhovor další. K tomuto postupnému výběru často dopomáhali i sami žáci, se kterými byly vedeny rozhovory, protože ti dokážou své spolužáky dle vybraných faktorů charakterizovat přesněji než výzkumník. Sběr těchto dat byl ukončen ve chvíli, kdy došlo $\mathrm{k}$ jejich saturaci. Pro zvýšení jistoty toho, že jsou data skutečně nasycena, byly podniknuty krátké neformální rozhovory s dalšími žáky, které probíhaly o přestávkách, s cílem zjistit, zda je hodnoticí soud žákủ skutečně úplný, nebo se ve tř́dě vyskytují žáci, kteří vnímají situaci odlišně. Vzhledem $\mathrm{k}$ tomu, že odlišnosti nebyly nalezeny, byl tento způsob sběru dat ukončen po pořízení rozhovorů s osmi žáky. Dále byly realizovány rozhovory s vyučujícími s cílem zjistit podobu výuky a spokojenost učitele s výukou v sextě A. S učitelem českého jazyka a literatury Čapkem byly pořízeny dva rozhovory (213 minut) a s učitelem matematiky Pythagorem jeden (100 minut). ${ }^{6}$ Záznamy všech rozhovorů byly převedeny do podoby transkriptu a podrobeny otevřenému kódování. ${ }^{7}$

Poté, co byla data podrobena otevřenému kódování, ze kterého vzešly první induktivně odvozené kategorie, by měly dle tradiční zakotvené teorie následovat další fáze kódování dat, abychom tak mohli dospět k výslednému modelu. Pro tuto př́ležitost však nebylo využito klasického axiálního a selektivního kódování, ale bylo využito novějšího způsobu práce s daty v zakotvené teorii (Clarke, 2003; Charmaz, 2006), kterým je situační analýza. Ta si klade

\footnotetext{
Učitel českého jazyka a literatury Čapek je zároveň tř́́dním učitelem sexty A, proto s ním byly vedeny dva rozsáhlejší rozhovory, které se týkaly i témat stojících mimo téma hodnocení výuky.

7 I zde vznikaly dvouúrovňové kódy, napřs: matematika: rychlé tempo výuky, čeština: vstrícný učitel.
} 
za cíl popsat příčinné vztahy (příčina-následek či strategie-cíl) mezi prvky situace a také je konkrétně specifikovat a zachytit jev v jeho komplexnosti (Clarke, 2005). Situační analýza tak nabádá výzkumníka, aby při zkoumání nebral zřetel pouze na jev samotný, ale na celou situaci, do níž je přirozeně zasazen a do které přináleží další aktéři a diskurzy (Kalenda, 2016). Situací rozumíme množinu neuspořádaných prvků, které svým působením utvářejí zkoumaný fenomén a jež lze doložit daty (Clarke, 2005). Stěžejním úkolem výzkumníka je postihnout co největší množinu těchto prvků a na základě analýzy je uspořádat. Prvním krokem je zpravidla otevřené kódování a následně tvorba situačních map, které jsou neustále komparovány s originálními daty a nejsou tak od počátku fixní a neměnné (Clarke, 2003). Situační mapy nejsou používány jako pouhé grafické znázornění výsledků výzkumu, ale slouží k zachycení myšlenkových procesů výzkumníka ve chvíli, kdy přemýšlí nad daty a na jejich základě vytváří novou teorii. Jde tedy o analytický nástroj, nikoliv pouze o prostředek zobrazení výsledků, i když i takové použití situačních map bývá běžné.

\section{Výsledky výzkumu}

Hledání odpovědi na otázku co je dobrá výuka neodmyslitelně patří k pedagogickému výzkumu i běžnému životu učitelů a žáků ve škole. I v tomto výzkumu padla podobná otázka, která byla položena žákům: kdybyste měli rozdělit předměty na dobré a špatné, jak byste je rozdělili a proč? Na jejím základě žáci hodnotili výuku jednotlivých vyučovacích předmětů (viz tabulku 1), přičemž uváděli řadu argumentů, které budou představeny dále v textu.

Značka plus v tabulce 1 znázorňuje kladné hodnocení výuky, značka mínus znázorňuje nelibé hodnocení a značka otazníku znamená, že se žáci nedokázali rozhodnout, jak by měli výuku daného vyučovacího předmětu ohodnotit. Na základě počtu udělených značek byly jednotlivé vyučovací předměty rozděleny do čtyř skupin. Nejlépe hodnocené vyučovací předměty se vyznačují pouze kladným žákovským hodnocením. Bezproblémové vyučovací předměty již nevynikají tak vysokou kvalitou jako ty nejlépe hodnocené, nicméně žáci ve výuce nespatřují výrazné problémy, a proto je nehodnotí značkou mínus. Nestabilní vyučovací předměty jsou takové, které žáci nejčastěji hodnotí značkou otazníku. Znamená to, že žákovské hodnocení je nestabilní a závisí na mnoha faktorech, které jsou proměnlivé, jako je např́iklad nálada, se kterou učitel přichází do výuky, a podobně. Špatné vyučovací předměty se pak vyznačují tím, že jim žáci připisují velký počet značek mínus. 
Tabulka 1

Přehled žákovského hodnocení výuky

\begin{tabular}{|c|c|c|c|c|c|}
\hline $\begin{array}{l}\text { Vyučovací } \\
\text { předmět }\end{array}$ & Jméno učitele & + & $?$ & - & $\begin{array}{l}\text { Zařazení vyučovacího předmětu } \\
\text { do skupiny }\end{array}$ \\
\hline Zeměpis & Hanzelka & $8 x$ & & & \multirow{3}{*}{ Nejlepší vyučovací předměty } \\
\hline ZSV & Frankl & $8 x$ & & & \\
\hline ČJ a literatura & Čapek & $8 \mathrm{x}$ & & & \\
\hline Anglický jazyk & Stuartová & $6 x$ & $2 x$ & & \multirow{3}{*}{ Bezproblémové vyučovací předměty } \\
\hline Dějepis & Kosmová & $6 x$ & $2 x$ & & \\
\hline Latina & Cézarová & $4 \mathrm{x}$ & $2 x$ & & \\
\hline Chemie & Mendělejev & $3 x$ & $5 x$ & & \multirow{4}{*}{ Nestabilní vyučovací předměty } \\
\hline Informatika & Jobsová & $3 x$ & $3 x$ & $2 \mathrm{x}$ & \\
\hline Německý jazyk & Habsburková & $1 \mathrm{x}$ & $3 x$ & $1 \mathrm{x}$ & \\
\hline Biologie & Mendelová & $1 \mathrm{x}$ & $6 x$ & $1 \mathrm{x}$ & \\
\hline Matematika & Pythagoras & $1 \mathrm{x}$ & $1 \mathrm{x}$ & $6 x$ & \multirow{2}{*}{ Špatné vyučovací předměty } \\
\hline Fyzika & Newtonová & $1 \mathrm{x}$ & & $7 x$ & \\
\hline
\end{tabular}

Pokud se žáků zeptáme, z jakého důvodu hodnotí výuku zrovna takto, své hodnocení staví zejména na tvrzeních týkajících se učitele. Nejde tak pouze o to, jak žáci hodnotí vyučovací předmět samotný nebo jeho výuku, ale jde zejména o to, jaký učitel jej vyučuje a jakým způsobem připravuje a realizuje výuku. Žáci tedy vnímají výuku především prizmatem svých učitelů (srov. Starý et al., 2012), a to mimo jiné znamená, že dobří učitelé z obyčejných vyučovacích předmětů vytvářejí předměty nejlepší. Důkazem budiž tvrzení Karla: „Frankl s Čapkem umí učit, protože učí předměty, který pro mě nejsou zajímavý, ale baví mě. Čeština, ten předmět rád nemám, ale mám rád profesora, a líbí se mi, jak to v té výuce funguje." Obdobná tvrzení, avšak v obráceném gardu, se vyskytují i v souvislosti s výukou matematiky, o čemž mluví Markéta: „Matika jako předmět mě baví, ale nebaví mě s Pythagorem.“

Žákovské hodnocení výuky je dynamickým procesem, a pokud v některém z vyučovacích předmětů dojde ke změně učitele, dochází i ke změně žákovského hodnocení výuky, což dokládá tvrzení Viktora: „Čapka jsme dostali na češtinu a najednou se nám změnila od toho, kdy jsme měli paní

8 Rozhovorů se žáky je osm, čili součet hodnoticích značek by měl být u každého vyučovacího předmětu osm. Nicméně ne všichni žáci navštěvují všechny jazyky, proto je u nich součet značek menší. $V$ tabulce 1 také absentuje výtvarná, hudební a tělesná výchova, ke kterým se žáci spontánně nevyjadřovali a nehodnotili je. 
profesorku Světlou, z hrozně utrápujícího předmětu, ze kterýho máme čtverky a nudnýho, stresujícího předmětu na zajímavej, dobrej, super předmět. A mě to baví. Čapek je jeden z mála profesorů, u kterýho jsem si fakt nikdy neříkal, proč tohle dělá? To bych snad i já udělal líp.“

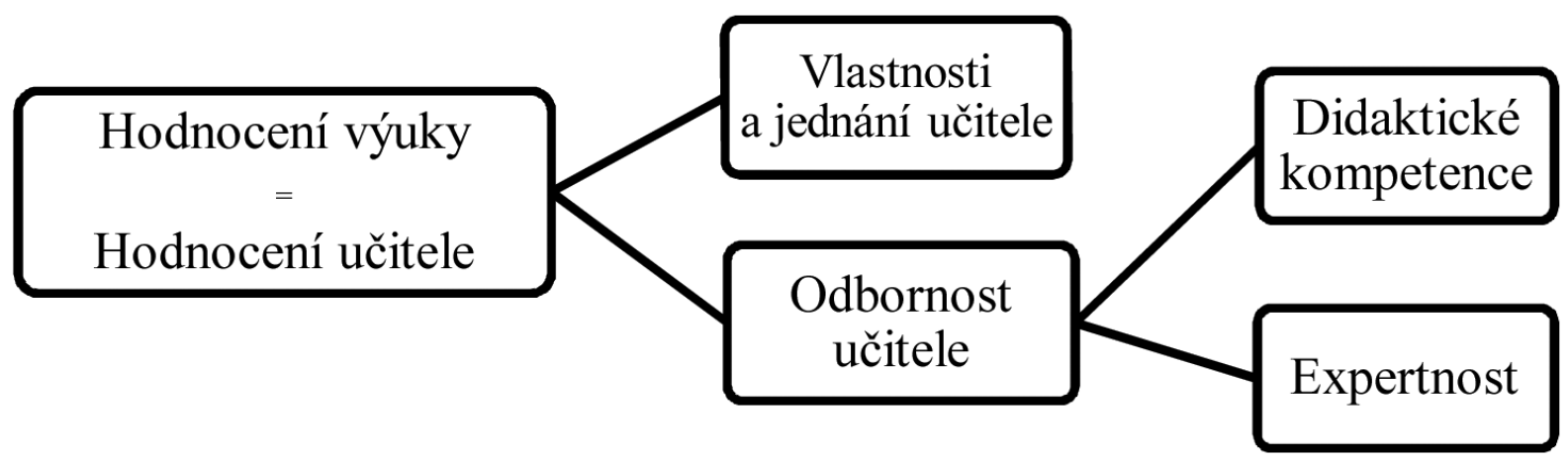

Obrázek 1. Základní oblasti žákovského hodnocení učitele

Ve chvíli, kdy žáci hodnotí učitele (viz Obrázek 1), se nejdříve zaměří na hodnocení toho, jaký učitel je. V první řadě tak hovoří o jeho vlastnostech a jednání. Pozitivně hodnotí zejména takové vlastnosti a jednání učitele, jako je vstř́ícnost, spravedlivé jednání, vnímání žáků jako partnerů ve výuce a podobně. Negativně pak žáci hodnotí zejména takové jednání, které označují jako nespravedlivé, př́liliš př́śné, nestabilní a tak podobně. Poté se žáci zaměřují na hodnocení výuky pod vedením učitele a začínají se tak vyjadřovat k jeho odbornosti, která se skládá ze dvou složek: expertnosti učitele, tedy znalostí obsahu výuky, a didaktických kompetencí, u nichž se žáci vyjadřují například k cílům, metodám a formám výuky, náročnosti výuky, spravedlnosti hodnocení žákovských výkonů, obsahu výuky apod. Žáci, přestože nejsou odborníky na vyučované téma po stránce odborné ani po stránce didaktické, učitele v těchto oblastech hodnotí. Co se týče didaktické stránky, tu žáci hodnotí jednoduše na základě toho, zda jim výuka vyhovuje, či nikoliv, a zda se dokážou učivo snadno naučit, či nikoliv. Jak ale žáci, jejichž odborné znalosti probíraného tématu jsou na počátku velmi nízké, mohou rozpoznat, zda je učitel expertem? Žáci v tomto ohledu sledují několik indikátorů, které jim v hodnocení pomáhají: např́íklad jak je učitel ochoten a schopen reagovat na žákovské otázky, jak učitel zachází s učebnicí či jinými didaktickými pomůckami (např́íklad o učitelce fyziky žáci doslova tvrdí, že „bez učebnice nedá ani ránu“) a podobně. 


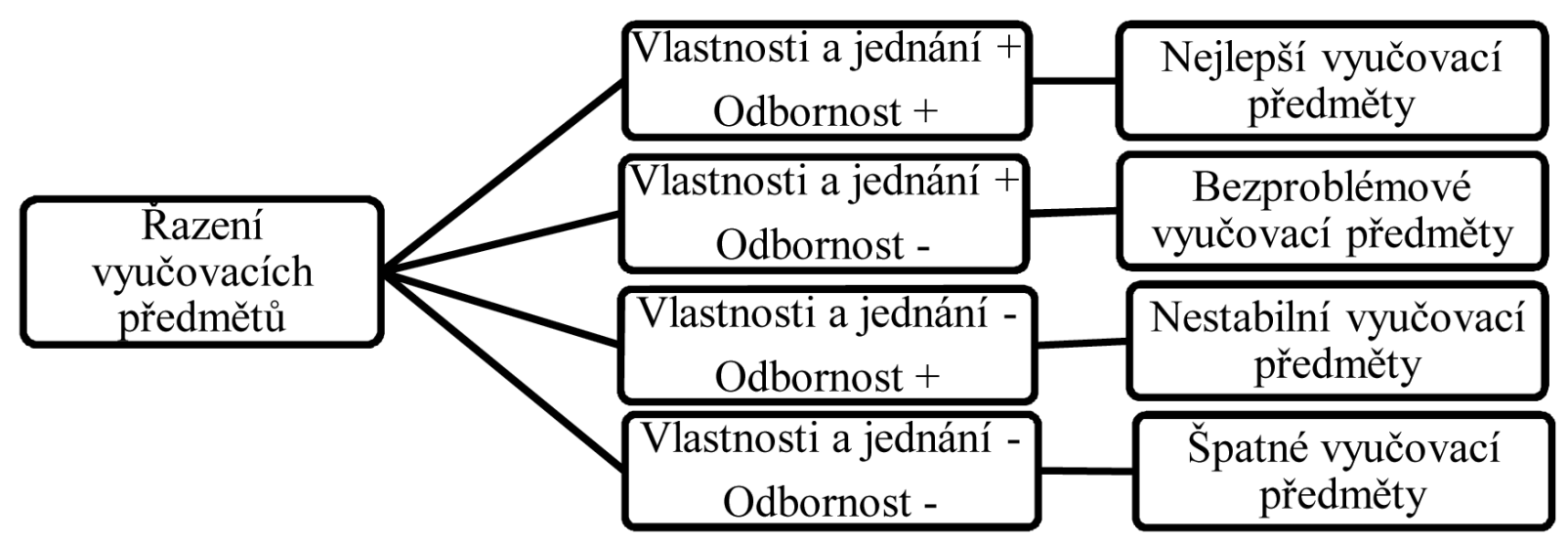

Obrázek 2. Žákovské hodnocení výuky dle hodnocení učitele.

Není to však odbornost učitele, která by pro žáky byla rozhodující. V žákovském hodnocení učitele hraje prim hodnocení jeho vlastností a jednání. Obrázek 2 je pouhým schematickým zachycením toho, o čem žáci hovoří, přesto jej můžeme považovat za vypovídající. Pokud jsou vlastnosti a jednání učitele žáky označeny značkou plus, je výuka takového učitele vždy hodnocena lépe, než pokud jsou učitelovy vlastnosti a jednání žáky označeny značkou mínus.

Žákovské hodnocení výuky však ve skutečnosti není př́lišs systematické. Téměř u každého vyučovacího předmětu a učitele si žáci všímají odlišných charakteristik, kterým připisují různý význam. Přesto lze v žákovském hodnocení výuky sledovat určitou pravidelnost. Pro účely tohoto textu byly vybrány dva vyučovací předměty, český jazyk a literatura, který patří mezi nejlépe hodnocené, a matematika, která se nachází na opačném konci hodnoticí škály. Mezi těmito dvěma vyučovacími předměty je viditelný kontrast, a proto právě na nich bude ilustrována ona pravidelnost v žákovském hodnocení výuky.

\section{1 Český jazyk a literatura: nejlépe hodnocený vyučovací předmět}

Učitel Čapek je dle žáků vstř́ícný, tolerantní a spravedlivý a žáci v jeho jednání neodhalili žádné vlastnosti hodné negativního hodnocení. Čapek má také smysl pro humor, a vyučovací hodiny se proto vyznačují př́ijemnou atmosférou, která se přenáší do dobrých vztahů mezi učitelem a žáky. Významným prvkem charakterizujícím jednání učitele je jeho partnerský př́istup k žákům. Vlastnosti a jednání učitele tak žáci hodnotí kladně. Na základě 
výpovědí žáků můžeme tvrdit, že odbornost učitele je také na vysoké úrovni. Žáci oceňují zejména Čapkovu dovednost práce s učivem, výběr a povahu výukových cílů i výběr metod výuky. Právě tyto tři prvky budou podrobněji popsány v následujících řádcích.

Žáci vyzdvihují učitelovu dovednost zpracovávat obsah výuky tak, že žáky dokáže zaujmout jak samo učivo, tak způsob jeho předávání. Můžeme tak sledovat, že Čapek vhodně uplatňuje didaktickou znalost obsahu (Shulman, 1986). Žáci tvrdí, že taková výuka je baví, a učiteli se daří vytvářet př́iemný prostor pro učení, budit $\mathrm{v}$ žácích zájem o učivo, a tím je motivovat $\mathrm{k}$ učení. Ondřej k tomu ř́ká, že „čeština je v pohodě, je zajímavá, děláme různý věci, co nejsou jenom gramatika nebo věci zpaměti, ale i o nějakým tom umělcovi; nebo jenom rozbor textu, ale občas mi to přijde propojený s životem, nebo že rozebíráme zprávy a věci, co nás zajímají." $V$ této souvislosti žáci dále tvrdí, že je toho učitel „hodně naučí. ${ }^{9}$ To znamená, že učivo v hodině nabyté žáci dokážou široce uplatnit jak ve škole, tak mimo ni. Takové učivo je dle žáků smysluplné, což je pro žáky důležité a ukazuje to na subjektivně vnímanou efektivitu výuky pod vedením učitele Čapka.

Mimo jiné z těchto důvodů ve výuce učitele Čapka vládne kázeň, na což upozorňuje např́klad Čeněk, který říká: „Ale vtipný je, že v ZSV, zemáku a češtině jsme nejvíc ticho ze všech, protože to je tak jediný, kde se dozvíme něco zajímavýho." Čeněk nemá na mysli ticho v tom smyslu, že by žáci nevstupovali do komunikace s učitelem, ale že si při výuce nepovídají mezi sebou, jak to mají ve zvyku u jiných vyučujících. Naopak věnují svou pozornost výuce a plní učitelovy požadavky, protože mají o výuku a učivo zájem. Eliška poukazuje na to, že chování žáků při výuce je do jisté míry reciproční, když ř́ká: „Mně připadá, že v češtině se chováme dobře, protože se nemáme důvod chovat špatně."

V souvislosti s výukou učitele Čapka žáci hovoří o spojitosti učiva s praxí či mimoškolním životem. I učitel Čapek tvrdí, že jeho cílem je propojování výuky s reálným životem.

Minulej tejden se mi zvedl žaludek, když jsem jel pro dceru a vedle mě si sedla holka, která měla otevřenej sešit. Fakta měla podtrhaný a naučila se za tu jízdu Puškina, Lermontova a pak ještě snad Poa. Mně přišlo hrozný už jenom to,

Z Žáci tím neodkazují na množství učiva, ale na množství toho, co se ve skutečnosti naučí. Rozdíl můžeme sledovat u předmětů špatně hodnocených, $v$ nichž učitel předává velké množství učiva, ale žáci tvrdí, že si toto učivo osvojí pouze z malé části. 
jakým způsobem se do toho dívala. To je absurdní, že si to tam prostě nahraje, a protože ta úča to chce slyšet, tak jí to vyplázne. Tak jsem si říkal, že tohle nechci. Kromě toho mám taky cíl, aby nad věcma přemejšleli, a nemusí se to týkat jenom literatury. Aby si uvědomovali, když ted' bereme národní obrození, že se v tom odráží naše mentalita, taková ta naše malost, která by chtěla být velká. A tak toužíme po tom se vyrovnávat těm jinejm národům, a když se nám to nedaří, tak zpochybňujeme vlastnosti těch ostatních, že se jim vysmíváme. A že pořád je z toho cítit ta zapšklost toho malý člověka českýho. Ale že tam byla určitá skupina lidí, která měla tu energii, která nás dovedla až sem. Tak aby tam nějakou tu linii viděli, aby se neučili jenom to, co je, ale aby vnímali, že to byla realita. Aby přemýšleli, všímali si. (Čapek)

Takto učitel Čapek popisuje cíl, který si uložil splnit. Zároveň se tímto vymezuje vůči učitelům, kteří vyučují převážně fakta, což je dle něj na gymnáziu nepřijatelné. Čapkův cíl tedy nespočívá ve výuce faktů, ale v motivaci žáků k hledání souvislostí, přemýšlení nad učivem, vyhodnocování př́ínosu učiva a podobně. Těchto Čapkových cílů si všímají i žáci, což komentuje Linda: „To, jakým způsobem Čapek tu látku podává... myslím si, že není spokojenej s tím, jak je ten školní systém zavedenej. A snaží se proti tomu bojovat." Linda tímto mimo jiné upozorňuje na skutečnost, že výuka učitele Čapka se liší od výuky řady ostatních vyučujících. Hlavní zdroj této odlišnosti spatřuje v nespokojenosti učitele Čapka s podobou výuky v hlavním proudu reprezentujícím převládající kulturu školy.

S cíli výuky úzce souvisí i metody výuky (viz tabulku 2), ke kterým se žáci hojně vyjadřují a které hodnotí kladně. Žáci si cení především toho, že výuka je vedena v módu, kterému ř́kají diskuse, kdy se učitel snaží do výuky zapojit co největší množství žáků. Tuto situaci popisuje Linda:

Mě hrozně baví diskuze s ním, když je nějaký žhavý téma. Stokrát jsme diskutovali téma: Miloš Zeman. $Z$ toho vznikly několikahodinové diskuze, což bylo super! Každej na to řekl svůj názor a bylo to hodně zajímavý. Ale to není kvůli tomu, že bysme chtěli přeskočit to učivo, ale fakt nás to baví.

Linda poukazuje na možný předsudek, který čas od času obestírá tuto metodu výuky, tedy že diskuse bývá neúčelná a nevztahuje se k probíranému učivu. ${ }^{10}$ Linda však dále hovoří o tom, že na základě zmíněné diskuse vznikl oficiální dopis, při jehož tvorbě žáci trénovali dovednost psaní dopisu a s tím

10 O problematice účelnosti diskuse (triadické interakce) je přehledně pojednáno $\mathrm{v}$ knize od autorů, kteří se věnují dialogickému vyučování (viz Šed'ová et al., 2016). 
související dovednost strukturovaného písemného projevu a formulování myšlenek a argumentů, což je součástí kurikula českého jazyka a literatury.

Tabulka 2

Metody výuky ve výuce českého jazyka a literatury ${ }^{11}$

\begin{tabular}{lclc}
\hline Metoda výuky & Zastoupení v \% & Metoda výuky & Zastoupení v \% \\
\hline $\begin{array}{l}\text { Rozhovor učitele } \\
\text { a žáků }\end{array}$ & 39 & Prezentace žáků & 9 \\
Přednáška s otázkami & 12 & Práce s informacemi & 8 \\
$\begin{array}{l}\text { Analýza textu } \\
\text { Přednáška bez }\end{array}$ & 11 & Vlastní tvorba žáků & 7 \\
otázek: výklad & 10 & Společné čtení & 4 \\
\hline
\end{tabular}

Z tabulky 2 je patrné, že žákovské označení výuky jako diskusní má reálné základy a skutečně jde o charakteristický rys výuky, který se nevyskytuje pouze útržkovitě a náhodně. Tradiční výklad, který obyčejně ve výuce dominuje (srov. Maňák \& Janík, 2009), je zde zastoupen v $10 \%$, a pokud je použit, zabírá maximálně deset minut souvislého času vyučovací hodiny. Při výkladu učitel představuje nové učivo, $\mathrm{k}$ čemuž si dopomáhá powerpointovou prezentací, na které jsou zachyceny informace určené k zapamatování. Čapkův výklad vyniká př́jemností na poslech a připomíná spíše vyprávění poutavých př́iběhů než výklad učiva.

Z tabulky 2 je dále zřejmé, že nejhojněji zastoupenou metodou výuky je rozhovor učitele a žáků (39 \%), který se vyskytuje ve chvíli, kdy učitel se žáky vyhodnocuje učební úlohy a pokládá otázky související se zadaným úkolem. Často jsou to i sami žáci, kteř́i pokládají otázky učiteli nebo spolužákům. Při tom docházejí ke společnému získávání fakticky správných informací a ověření správnosti jejich použití při plnění učební úlohy. Dále v pořadí následuje přednáška s otázkami (12\%), při které učitel pokládá velké množství jak otevřených, tak uzavřených otázek nižší i vyšší kognitivní náročnosti. Na tyto otázky žáci v drtivé většině případů odpovídají správně. Tato metoda výuky bud' předchází zadání učební úlohy, nebo naopak slouží jako shrnutí učiva, které učební úloha ilustrovala.

11 Metody výuky byly charakterizovány a pojmenovány na základě otevřeného kódování videonahrávek vyučovacích hodin českého jazyka a literatury, konkrétně se jednalo o literární část výuky. Procenta uvedená v tabulce značí, kolik procent celkového času pozorovaných vyučovacích hodin zabírá ta která metoda výuky. 
Obě tyto metody výuky ${ }^{12}$, jakožto chvíle, kdy se učitel dostává do přímé komunikace se žáky, společně zabírají 51 \% výuky, a tím jsou netypicky hojně zastoupeny. Typicky totiž ve výuce vládne výklad, který je prokládán takovou formou komunikace, kterou označujeme jako IRF struktura (Švaříček, 2011). Čapek však při výuce hojně využívá prvků tzv. dialogického vyučování, které spočívá v živé komunikaci učitele a žáků o učivu a skládá se zejména z otevřených otázek vyšší kognitivní náročnosti, rozvinuté zpětné vazby (uptake) a triadické interakce, což je něco jako diskuse (viz Šed'ová, Švaříček, \& Šalamounová, 2012; Šed’ová et al., 2016).

Čapkův způsob výuky mimo jiné způsobuje, že žáci jsou do vyučovací hodiny aktivně zapojeni, a mohou tak ovlivnit její průběh. ${ }^{13}$ Opět můžeme říci, že jde o poměrně netypickou situaci, protože typicky se ve výuce setkáváme s velmi aktivními učiteli a pasivními žáky (srov. Najvar et al., 2011), což při vyučování vede k nudě (Čejková, 2014), neoblíbenosti vyučovacího předmětu či učitele, zhoršenému školnímu prospěchu a nelichotivému postoji žáků ke škole (srov. Hrabal \& Pavelková, 2010). Zajímavé je také to, že žáci se dobrovolně zapojují do výukové komunikace bez ohledu na prospěch, přičemž doposud se mělo za to, že do výukové komunikace se zapojují především žáci s lepším prospěchem (Šed'ová, Sucháček, \& Majcík, 2015) a také žáci v tzv. zóně dominantní aktivity učitele, někdy též T-zóně (více viz Bradová, 2012), přičemž při výuce učitele Čapka neplatí ani tento předpoklad.

Výše popsaným způsobem vyučování učitel vede žáky jednak k osvojení si stanoveného učiva, ale také k získání potřebných kompetencí a dovedností. V této souvislosti žáci aktivně poukazují na to, že značnou část učiva není nutné učit se takzvaně zpaměti. To žáci považují jednak za velmi příjemné, a také mají za to, že učivo takto nabyté dokážou snáze pochopit, neb je učitel vede spíše k porozumění učivu, nikoliv k jeho pouhému zapamatování. Tyto žákovské teze je možno potvrdit prostřednictvím analýzy učebních úloh. Za tímto účelem bylo využito Bloomovy taxonomie (Anderson \& Krathwohl, 2001), která vyjadřuje výši zapojení myšlenkových operací prováděných žáky při plnění úlohy. Z této analýzy vyplývá, že nejhojněji zastoupenými jsou úlohy vyžadující analýzu a syntézu (30 \%) a zapamatování (22 \%). Úlohy vyžadující zapojení vyšších myšlenkových operací tak dosahují ve výuce

2 Tím je míněn rozhovor učitele a žáků a přednáška s otázkami.

13 Žáci a učitel jsou aktivní společně v 51 \% výuky (součet metod výuky: rozhovor učitele a žáků a přednáška s otázkami). Žáci sami jsou aktivní v 39 \% výuky (součet metod výuky: práce s textem, prezentace žákủ, práce s informacemi, vlastní tvorba, společné čtení). Učitel sám je aktivní v 10 \% (přednáška bez otázek: výklad). 
$78 \%$, což je neobvyklé, protože ve výzkumných zprávách se dočteme, že výuce vévodí spíše úlohy či otázky zaměřené na nejnižší úroveň kognitivní náročnosti (srov. Švaříček, 2011).

Závěrem lze říci, že žáci jsou s výukou pod vedením učitele Čapka spokojeni a učitel Čapek je u žáků oblíben. Spokojen je i Čapek se třídou a tvrdí, že se mu v sextě A vyučuje dobře a neidentifikuje žádný problém. Představa učitele o dobré třídě spočívá v tom, že žáci ve výuce komunikují a spolupracují, což sexta A splňuje. Čapek naopak tvrdí, že nerad vyučuje ve třídách, kde jsou žáci pasivní: „Co je nejhorší, že tihleti lidi, který mlčí, jsou vnímaný jako ti, který se správně chovají. To mně přijde úplně nejzvrhlejší. Pokud sedíš, mlčíš a zapisuješ si, tak je to v pohodě." Čapek poukazuje na skutečnost, že do kultury školy patří spíše názor, že tiší žáci jsou právě těmi, kteří se ve škole chovají správným způsobem. Je evidentní, že Čapek s touto kulturou školy nesouzní, a zřejmě i proto je žáky hodnocen jako dobrý učitel.

\subsection{Matematika: špatně hodnocený vyučovací předmět}

$\mathrm{V}$ př́padě výuky matematiky žáci spatřují problémy jak ve vlastnostech a jednání učitele, tak $\mathrm{v}$ jeho odbornosti. Na Pythagorovy vlastnosti a jednání žáci pohlíží negativně a říkají, že učitel je zásadový, přísný a často jedná nespravedlivě či nepředvídatelně. Situaci podtrhuje i Pythagorova zvláštnost v chování.

My jsme s Janou probíraly takovou teorii, že by mohl mít nějakou formu autismu. Bílý trička, nepřrišel ani jednou v jiný barvě, stejný boty, stejný kalhoty. V levé kapse na zadku má látkový kapesníček. Pokaždé, když něco napíše kř́idou na tabuli, i když třeba za patnáct sekund bude psát něco znova, tak si jde umýt ruce, vyndá si ten kapesníček, bez toho aniž by ho otevíral, si utře ruce a zasune si ho zpátky. Takovej méd’a. Ale s takovýmhle člověkem nepohneš. (Linda)

Učitel si od žáků za dobu svého krátkého působení v sextě $\mathrm{A}^{14}$ nevysloužil lichotivý popis. Žáci se hojně vyjadřují k jeho šatníku a stereotypnímu chování, což s výukou matematiky zjevně nesouvisí. Avšak i tato drobnost se negativním způsobem promítá do žákovského hodnocení výuky a ovlivňuje názor žáků na učitele, což přibližuje Markéta: „On je takovej divnej a mě děsí. Nejsem jediná, kdo má názor, že je divnej a strašidelnej." Tento náhled žáků na učitele rovněž negativně ovlivňuje vzájemnou komunikaci, což žáci přičítají

$\overline{14}$ Učitel Pythagoras v té době působil v sextě A cca pět měsíců. 
povahovým rysům učitele. Problémy v komunikaci vnímá i Pythagoras, avšak na rozdíl od žáků je spojuje spíše s didaktickými kompetencemi.

Jsem si vědom, že by to šlo $v$ hodinách vést lépe, že ta komunikace se tř́ídou, v tom mám mezery. Ale z mého pohledu to nejsou mezery, který by měly představovat až tak velký problém. Žáci mají čas si na to zvyknout. Myslím si, že se chovám konstantně, neřvu na ně, nedělám schválnosti. (T: Když ř́́káte, mezery v komunikaci, jak si to mám představit?) Dělám chybu, že s nima tolik nemluvím. Ted’ už mi to ale přijde zbytečný pořád je napomínat. Jsou dost starý na to, že když jim řeknu, že si nemají hrát s mobilem, tak že by si neměli hrát s mobilem. (Pythagoras)

Pythagoras tento komunikační nedostatek dává do souvislosti s množstvím komunikačních aktů, kterými rozumí napomínání žáků ve výuce, což ale není ve shodě s definicí pedagogické komunikace (srov. Průcha, Walterová, \& Mareš, 2009). Učitel o tomto nedostatku dále hovoří jako o nepř́liš palčivém problému a je přesvědčen, že žáci se jeho stylu komunikace mohou přizpůsobit.

Můžeme shrnout, že učitelovy vlastnosti a jednání žáci nepovažují za vhodné. Co se týče odbornosti učitele, zatímco žáci jsou ochotni říci, že Pythagoras je expertem na matematiku, nejsou ochotni říci, že má rozvinuté didaktické kompetence. Žáci ve výuce matematiky spatřují především problémy, kterými jsou pasivita žáků při vyučování, což je v přímém rozporu s nejlépe hodnocenou výukou, dále nízká kognitivní náročnost výuky a s tím spojená nízká efektivita výuky.

Pokud se vydáme po stopách odbornosti učitele, zjistíme, že se žáci hojně vyjadřují především $\mathrm{k}$ metodám výuky, mezi nimiž dominuje výklad doplněný o výpočty př́kladů z učebnice. Žáci tvrdí, že mají za to, že „Pythagoras vyučuje s jediným cílem, kterým je odpřednášet učivo a odejít." Učitel je tedy orientován na předávání učiva (Trigwell \& Prosser, 1996), nikoliv na žáky a žákovské učení. Tuto problematiku přibližuje Karel: „Ty hodiny s ním jsou prostě nudný a učivo, co od něj dostanu, si nedokážu zapamatovat. I když se hodně snažím, tak se musím matematiku učit sám." Taková výuka se žákům jednak jeví jako nudná, jednak ji vnímají jako neefektivní, protože učivo, které učitel žákům tímto způsobem předává, nedosahuje kýženého impaktu.

Na otázku Co bych viděla, kdybych přišla do Vaší hodiny? Pythagoras odpovídá: „Ve tř́́dě to vypadá klasicky, frontální výuka. Vyloží se teorie a dělají se základní př́íklady. Většinou je dělám já sám na tabuli, aby to bylo v pořádku, 
abych měl zaručeno, že to poběží hladce. Pak se přejde k př́́kladům z učebnice, které už střídavě řeší studenti u tabule." Učitel popisuje výuku podobně jako žáci a tvrdí, že výuka matematiky v jeho podání vypadá klasicky. Kde se však bere ono označení a co přesně znamená, není zřejmé. Můžeme se domnívat, že za klasickou metodu výuky učitel považuje výklad a pak také výpočty příkladů, které však často provádí sám učitel a teprve později jsou k provádění výpočtů přizváni i někteří ze žáků.

Výše popsaný způsob výuky matematiky naznačuje, že přesto, že by matematika měla být vyučována zejména na úrovni aplikační, ${ }^{15}$ nejčastěji je vyučována na úrovni zapamatování, což je implikováno způsobem předávání učiva, tedy použitou metodou výuky. Tematika učení se zpaměti je učitelem zdůrazňována jako problém. Jeho výuka $\mathrm{k}$ tomuto způsobu učení nicméně vede a učitel tím podporuje žáky v povrchovém či utilitárním způsobu učení se. To v dlouhodobém časovém horizontu nemá tak dobré výsledky jako hloubkové učení se (Ramsden, 2003; Race, 2007), které je založeno právě na porozumění a schopnosti aplikace učiva. Učitel zároveň nemá ve svém repertoáru nástroje, kterými by byl schopen proměnit způsob žákovského osvojování si učiva.

V souvislosti s odborností učitele Pythagora žáci zmiňují, co považují za základy a nedílnou součást učitelské profese, a poukazují na to, že Pythagoras toto neovládá. Mezi tyto základní dovednosti učitele žáci řadí: schopnost získat pozornost žáků (Viktor: „Mně přijde, že každej profesor by měl bejt schopný udržet si pozornost žáků. Ale tím, jak pan profesor k tomu přistupuje, tak tu pozornost ztratí."), schopnost jasně vysvětlovat učivo (Mirka: „Já si myslím, že když někdo něco nechápe, tak opravdu nepomůže, když to Pythagoras vypočítá za nás. Tím říkám, že to nedokáže vysvětlit."), schopnost motivovat žáky $k$ učení se (Karel: „Většina lidí nedokáže najít důvod, proč by se měli učit matematiku, proto potřebujou profesora, kterej je k tomu povede a něco je naučí. A to on nezvládl.") a také schopnost nastolit ve výuce kázeň, což vysvětluje Eva: „Já chápu, že Pythagora asi nebaví celé hodiny nás okřikovat, ale je to součást práce učitele. Když jsme měli profesorku Světlou, tak ta na nás zakřičela a donutila se nás učit, a potom byl ve třídě klid." Eva popisuje dva zajímavé momenty. Jedním z nich je jakési obrácení rolí, při kterém žáci požadují, aby byli učitelem ukázňováni. Druhým z nich je, že Eva

15 Dle Bloomovy taxonomie kognitivní náročnosti výukových cílů a charakteristiky výuky matematiky podle Rámcového vzdělávacího programu pro gymnázia (2007; dále jen RVPG). 
ztotožňuje kázeň s žákovskou motivací k učení se. Znamená to tedy, že pokud učitel nedokáže žáky ukáznit, nemůže je naučit předepsané učivo. Můžeme také vyzdvihnout, že nekázeň ve výuce je jedním z viditelných ukazatelů žáky špatně hodnocené výuky. Spíše než o tradiční nekázeň, projevující se rušivým chováním, jde o pasivitu žáků, což popisuje Čeněk: „Kdyby někdo přišel do matematiky, tak by viděl, že půlka lidí spí, třetina tupě zírá na tabuli a neví, co se děje, a třetina něco píše, ale ne, že by je on něco naučil, ale že už to vědí."

S výše uvedenými charakteristikami výuky a učitele se pojí stěžejní téma, kterým je prospěch žáků, kdy známky mnohých z nich jsou na hranici neúspěchu. Dle žáků je důvodem jejich špatného prospěchu právě nekompetentnost učitele. Pythagoras však spatřuje důvody v nízké snaze žáků učit se matematice: „Oni by, podle mě, měli sami. Já v hodinách procházím třídou. Když nepracují, tak si ř́ikám ,co já je budu nutit'. A když vidím, že pracují, tak se zeptám, jestli by to nešlo řešit jinak. Oni to vnímají ze třídy negativně, že se věnuji primárně těm dobrým. Ale z mého pohledu se věnuji těm, který se tomu sami věnují." To, zda žáci chtějí, se projevuje tím, že v hodině vzorně pracují a dosahují správných výpočtů příkladů. Jsou to tedy žáci, kteří matematiku dobře ovládají, kterým se Pythagoras věnuje především. Pythagoras dále přibližuje, co se musí stát, aby se věnoval i žákům, kteří se dle jeho soudu nechtějí věnovat matematice: „Žákům jsem ř́́kal, že potřebují splnit tři věci. Musí znát, co mají znát do ted'. Mají dávat pozor v hodině. A když něčemu nerozumí, mají se zeptat. Až tohle splní, tak budu vymýšlet, jak pomoct." Učitel si tímto klade podmínky, které by žáci měli splnit, a vyžaduje, aby byli žáci více aktivní, ukáznění a samostatní.

V souvislosti se špatným prospěchem žáků se vyskytuje fenomén, kterému žáci i učitelé říkají fyzikální chřipka. ${ }^{16}$ Ta spočívá v tom, že žáci při písemných pracích z matematiky údajně ve větším počtu absentují: „Stalo se mi hodněkrát, že absence $v$ den písemky byla větší než normálně. Evidentně. Řešil jsem to i s třídním. Samozřejmě nemám důkazy, může to být náhoda, ale stává se to pravidelně. A pak ti, co si písemku dopisují, tak vědí, z čeho byla, jaké typy prríkladů, tak je jejich známka lepší." Podobnost příkladů při náhradním termínu je zřejmě důvodem, proč žáci pravděpodobně nepřicházejí na první termín písemné práce. Očekávají totiž, že se zadání testu dozvědí od spolužáků a budou se moci lépe připravit. Zároveň může také jít o způsob odboje či projev rebelie žáků (srov. Woods, 2012), kterým dávají najevo, že výuka

16 Fenomén je pojmenován podle fyziky, v níž se začal objevovat dříve než v matematice. 
matematiky není vyhovující. Žáci se vyhýbáním písemným pracím chtějí vyvarovat negativních dopadů takové výuky v podobě špatného prospěchu.

Veškeré výše popsané problémy spojené s výukou matematiky mají původ v momentě, který popisuje Viktor:

U Pythagora je špatně, že hrozně debilně nastoupil a choval se jako hroznej kretén. Prostě nás vůbec nemotivoval a nastoupil hrozně rychle s tou látkou. My jsme se ho zeptali, jestli mu záleží víc na tom, aby nás aspoň něco málo naučil, abychom neměli všichni pětky, nebo jestli mu záleží víc na tom, aby stihl učební plán. Tak nám řekl, že aby stihl učební plán.

Viktor popisuje situaci, která nastala záhy poté, co došlo k výměně vyučujících v matematice, přičemž neváhá použít vulgarismů, které značí, že situace zřejmě byla emočně vypjatá. Pythagoras po převzetí výuky matematiky v učivu nenavázal v místě, kde skončila předchozí učitelka, ale začal vyučovat učivo, které žáci měli dle školního vzdělávacího programu aktuálně probírat. Na straně žáků tak vznikla propast v učivu, kterou nebyli schopni sami překonat. Žáci žádali učitele o doplnění chybějícího učiva, ten však jejich žádosti nevyhověl. To v žácích zanechalo negativní první dojem, který se doposud promítá do jejich hodnoticího úsudku. Tato situace také žáky podnítila ke snaze proměnit podobu výuky prostřednictvím zaslání dopisu adresovaného Pythagorovi, ve kterém žáci vylíčili problémy, které ve spojitosti s výukou vnímají, a ve kterém požadovali řešení situace. ${ }^{17}$

Na otázku, jak se učiteli ve třídě vyučuje, Pythagoras odpovídá:

Od té doby, co mi poslali ten dopis, v té třídě učit je né moc př́ijemné. Ale já tu svoji chybu prostě nevidím. A s tou tř́dou mám problém, že tam jsou dvě sekce. Ti dobří, se kterými se pracuje úplně parádně. S tou druhou, tam vidím letargii, že se jim nechce, že si to chtějí jen odsedět, a podle mě tam ani nejsou znalosti.

Pythagorova slova jsou v rozporu s modelem kvalitní školy (srov. Chvál, 2018; ČŠI, 2016), který říká, že učitel má brát zřetel na potřeby žáků, ke kterým má přistupovat individuálně za účelem rozvoje každého z nich. Od chvíle, kdy Pythagoras od žáků obdržel dopis, poukazuje na nedostatky žákủ a žádá jejich odstranění. Momentálně jsou tedy žáci a učitel v souboji o to, čí představa o dobré výuce je správná.

17 Problematika spojená se zasláním dopisu bude předmětem některého z př́štích textů. 


\section{Závěr a diskuse}

Otázkou řešenou v tomto výzkumu bylo: Jak žáci gymnázia hodnotí výuku jednotlivých vyučovacích predmětů? Odpovědi byly ilustrovány na základě příkladů žákovského hodnocení výuky českého jazyka a literatury a matematiky. Můžeme shrnout, že žáci hodnotí výuku především prizmatem svých vyučujících (srov. Starý et al., 2012), které hodnotí ve dvou ne zcela rekurzivních oblastech, a to v oblasti vlastností a jednání a oblasti odbornosti.

Vlastnostem a jednání učitele žáci připisují větší význam a považují je za důležitější než odbornost učitele. Zejména hodnocení efektivity výuky bylo ve svých počátcích nahlíženo právě skrze charakteristické vlastnosti učitele. Od tohoto náhledu se však výzkumníci postupem času odklonili a začali se věnovat výzkumu „proces-produkt“, tedy vztahu mezi činností učitele a vzdělávacími výsledky žáků. Scheerens (2004) však deklaroval pozvolný návrat ke zkoumání osobnostních charakteristik učitele, k čemuž přispívá i tento výzkum.

V rámci odbornosti učitele se žáci vyjadřují k expertnosti učitele, tedy jeho znalostem obsahu a didaktickým kompetencím. Tyto oblasti rovněž nebývají vždy rekurzivní čili pokud je učitel žáky označen jako expert, nemusí to vždy znamenat, že jeho didaktické kompetence jsou na vysoké úrovni, a opačně. Tento stav, kdy i v profesní přípravě učitelů často vede poměrně ostrá hranice mezi oborovými a pedagogickými či didaktickými znalostmi, se stal předmětem kritiky již před několika lety. Na základě této kritiky Shulman formuloval pojem didaktická znalost obsahu, který obě oblasti spojuje (Shulman, 1986; srov. také Janík, 2007, 2008, 2009). Znamená to tedy, že nestačí, aby učitel byl expertem na obsah, ale také je žádoucí, aby dokázal tento obsah žákům efektivním způsobem předat. $\mathrm{Z}$ výsledků výzkumů didaktické znalosti obsahu zřetelně vyplývá, že učitel-začátečníci (což je právě případ učitele Pythagora) nedisponují tak rozsáhlým repertoárem strategií pro zpracování učiva a hůře tak mohou najít cestu $\mathrm{k}$ tomu, jak učivo nejlépe žákům předat (srov. Janík, 2009).

Co se týče hodnocení samotné výuky českého jazyka a literatury a matematiky v podání obou učitelů, žáci se zaměřují zejména na kategorie znázorněné v tabulce 3 . 
Tabulka 3

Rozdíly mezi dobrou a špatnou výukou z pohledu žáků

\begin{tabular}{|c|c|c|c|c|c|c|c|c|}
\hline & 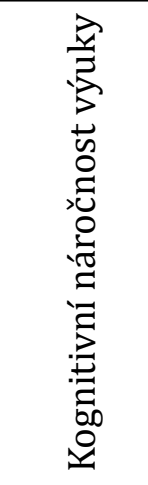 & 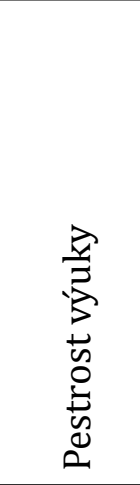 & 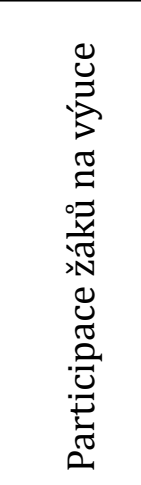 & 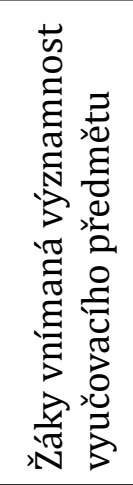 & 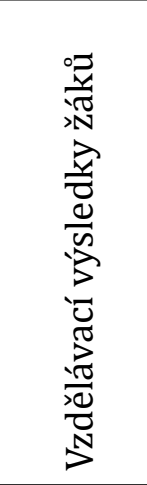 & 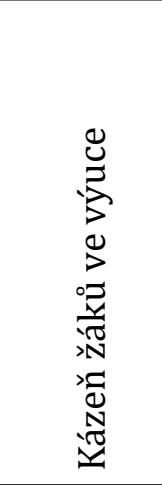 & 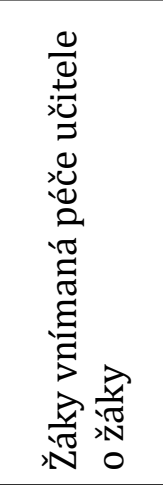 & 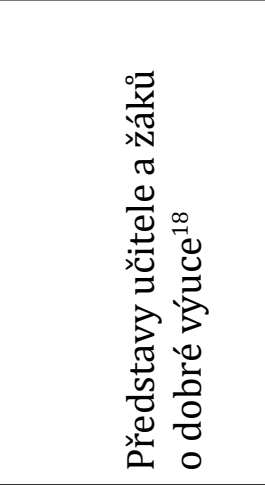 \\
\hline $\begin{array}{l}\text { Dobrá } \\
\text { výuka }\end{array}$ & vysoká & vysoká & vysoká & zjevná & dobré & kázeň & $\begin{array}{l}\text { pečující } \\
\text { učitel }\end{array}$ & $\begin{array}{l}\text { představy žáků } \\
\text { a učitele jsou } \\
\text { velmi podobné }\end{array}$ \\
\hline $\begin{array}{l}\text { Špatná } \\
\text { výuka }\end{array}$ & nízká & nízká & nízká & skrytá & špatné & nekázeň & $\begin{array}{l}\text { liknavý } \\
\text { učitel }\end{array}$ & $\begin{array}{l}\text { představy žáků } \\
\text { a učitele se } \\
\text { rozcházejí }\end{array}$ \\
\hline
\end{tabular}

Čapek je orientován na žáky a jejich učení se (Trigwell \& Prosser, 1996), to také znamená, že o žáky a jejich vzdělávací výsledky pečuje takovým způsobem, aby měl každý z žáků šanci na úspěch (srov. Chvál, 2018). Čapek by se také směle mohl hlásit ke konstruktivistické výuce, ve které je žákům přiznána aktivní role při učení a je jim nabídnuta celá řada př́ležitostí k objevování a vlastním interpretacím učiva prostřednictvím řady rozličných vyučovacích metod. Žáci ve výuce zabírají rozsáhlý komunikační prostor, a tím mohou do jisté míry ovlivňovat její průběh. Učitel využívá prvky dialogického vyučování (Šed'ová et al., 2016), a tím také povzbuzuje kognitivní aktivizaci žáků. Žáci tak na výuce českého jazyka a literatury velmi aktivně participují a učitel často ustupuje do pozadí a slevuje ze své dominance (srov. Šed'ová, 2011). V Čapkově výuce se také nezdá být pravdivé stereotypní tvrzení, že čím jsou žáci angažovanější, tím klesá intelektuální náročnost výuky, protože Čapkova výuka je kognitivně náročná. Žáci dále podotýkají, že efektivita Čapkovy výuky je na vysoké úrovni. Žáci jednak dosahují dobrých vzdělávacích výsledků, jednak tvrdí, že vědomosti a dovednosti ve výuce nabyté dokážou široce uplatnit jak ve škole, tak mimo ni. Čapkovi se také daří dostát

18 Jedná se o učiteli i žáky deklarovanou shodu na podobě dobré výuky. Např́íklad Pythagoras klade důraz na předávání velkého množství poznatků. Učitel to označuje jako dobrou výuku, zatímco žáci tento způsob vyučování hodnotí negativně. 
cílům výuky, které jsou stanoveny v RVP G (2007), což znamená, že se žáci učí také dovednostem, klíčovým kompetencím apod.

Pythagoras se upíná spíše k akademickým cílům školy a operuje tak v módu osvojování, což je metaforické označení pro výuku učitele, který je nositelem vědění, které ve výuce jednoduše předává žákům (Švaříček \& Čejková, 2016). Žáci jsou tak ve výuce velmi pasivní, a to jak po fyzické, tak po kognitivní stránce. Pythagoras ve výuce nedbá na rozvoj dovedností a klíčových kompetencí žáků a nezapojuje žáky do výuky tak, jak jej k tomu nabádá RVP G (2007), které zároveň označuje matematiku jako aplikační vyučovací předmět, čemuž Pythagorova výuka neodpovídá. Výuka matematiky pod vedením Pythagora je také typická rychlým tempem, při kterém žáci nezvládají vstřebávat předávané učivo. Rychlé tempo výuky může být způsobeno tím, že učitel předává předem připravenou sadu faktů, které on sám velice dobře zná. Žáci však učivo neznají a potřebují pro jeho osvojení více času, kterého se jim nedostává, přičemž právě čas je ve výuce potřebný (srov. Švaříček, 2013). Například také Carroll (1963) ve svém modelu školního učení operuje právě s časem potřebným pro učení a tvrdí, že čím méně je výuka kvalitní, tím více času žáci potřebují $\mathrm{k}$ tomu, aby se naučili požadované učivo. Výuka matematiky dle žáků není efektivní, protože nedosahují dobrých vzdělávacích výsledků a nevidí praktické využití učiva. Žáci také vnímají, že učitel nevěnuje žákům a jejich vzdělávacím výsledkům takovou péči, jakou by si žáci představovali. Sám učitel také dává žákům najevo, že jejich vzdělávací výsledky ovlivňují pouze oni sami.

Druhá otázka řešená v tomto výzkumu byla: zda žákovské hodnocení výuky může disponovat hybnou silou umožňující žákům ovlivňovat výuku směrem k její vyšší efektivitě a kvalitě. Poslední sloupec tabulky 3 ukazuje, zda se představa žáků a učitelů o dobré výuce shoduje. Žáci identifikují dva hlavní proudy učitelských představ o dobré výuce. Jednu skupinu učitelů charakterizují jako učitele, kteří považují za žádoucí aktivní zapojení žáků do výuky. Což je zároveň i představa žáků o dobré výuce. Druhou skupinu charakterizují jako učitele, jejichž výuka se vyznačuje tradiční kázní (srov. Bendl, 2005) a výraznou pasivitou žáků ve výuce. Což se neslučuje s představami žáků o dobré výuce. Dle výpovědí samotných učitelů lze vidět, jak se sami učitelé tu více, tu méně do obou těchto proudů řadí. U obou skupin učitelů mají žáci snahu být konformní a často tak dochází ke stavu hegemonie (Hargreaves, 1972), kdy učitel prosazuje své cíle a žáci se jim podřizují. $V$ případě dobře hodnocených předmětů jde o žádoucí stav. $V$ případě špatně hodnocených předmětů však 
může docházet $\mathrm{k}$ řadě konfliktů mezi žáky a učitelem, a to $\mathrm{v}$ případě, kdy se žáci snaží o kontrahegemonii, tedy o prosazování svých cílů ve výuce, které se rozcházejí s cíli učitele. Zatímco Čapek je schopen předvídat, zda v jeho výuce může dojít ke konfliktu, či nikoliv, Pythagoras tohoto schopen není. Čapek totiž od žáků pravidelně žádá zpětnou vazbu na svou výuku, na kterou pružně reaguje. I to je důvodem rovnovážného stavu ve výuce učitele Čapka a sladění představ žáků a učitele o tom, co je dobrá výuka. Samotné žákovské hodnocení výuky však nedisponuje hybnou silou vedoucí ke změně výuky až do chvíle, kdy žáci toto hodnocení sdělí svému učiteli. Zda žáci učitelům sdělují své hodnoticí stanovisko, či nikoliv, a zda tedy nechávají zaznít hlas žáků, včetně toho, jaký impakt jejich snaha má, naznačuje další možný směr bádání v této tematické oblasti.

Výzkum, který reprezentuje tento text, má své přirozené limity, které je potřeba mít na zřeteli. Např́klad vyučovací předměty český jazyk a literatura a matematika byly pro tento text vybrány s ohledem na limitovaný rozsah studie, kterou je možno publikovat. Neméně zajímavé je sledovat také závěry analýzy ambivalentního žákovského hodnocení, jako je tomu u předmětů nestabilních. Dále se můžeme ptát, zda je vůbec možné srovnávat výuku rodného jazyka a matematiky, jakož i dalších předmětů. Každý vyučovací předmět má svá specifika, každý z nich je také spojen s vlastní oborovou didaktikou, která říká, že učitelé různých předmětů do výuky vnáší odlišné cíle, metody, pomůcky a tak dále. Pro téměř každý vyučovací předmět jsou učitelé vzděláváni na jiné fakultě vzdělávající budoucí učitele pro střední školy. Tyto faktory musí nutně zohlednit každý výzkumník snažící se postihnout shody a rozdíly v žákovském hodnocení výuky jednotlivých vyučovacích předmětů. Ukazuje se však, že sami žáci v mezích, ve kterých uvažují výzkumníci, nepřemýšlí. Ti hodnotí výuku zcela pragmaticky a do značné míry i utilitárně.

V době, kdy na školách fungují žákovské samosprávy a kdy se žáci středních škol mohou sdružovat $\mathrm{v}$ řadě organizací, kdy zřejmě nejznámější z nich je České středoškolská unie, se nicméně otázka kvality a efektivity výuky vnímaná optikou středoškoláků stává otázkou stále naléhavější. Rudduck a Flutter (2000) tvrdí, že pokud chceme zlepšovat školu, a tedy i výuku, je potřeba se naladit na vnímání školy optikou žáků. Rodgersová (2006) na to konto prohlašuje, že je vhodné podporovat změnu současných despotických mocenských vztahů mezi učiteli a žáky, která se má odehrát právě na základě kritického hodnocení práce učitelů i žáků. Tvrzení Rodgersové by jistě podpořili i samotní sextáni, kteří jsou poměrně dobře schopni hodnotit 
výuku v rámci jednotlivých vyučovacích předmětů a přisuzovat jednotlivým charakteristikám výuky pozitivní i negativní významy, které jsou založeny na promyšlené argumentaci. Žákovské hodnocení výuky, ač má řadu limitů a nedostatků, můžeme považovat za významné a aktuální téma zejména $\mathrm{s}$ ohledem na skutečnost, že $\mathrm{v}$ posledních letech je v edukačních procesech stále více zdůrazňován partnerský přístup školy k žákům. Z toho důvodu je jistě vhodné téma žákovského hodnocení výuky a také hlasu žáků podrobit dalšímu bádání.

\section{Literatura}

Anderson, L. W., \& Krathwohl, D. (Eds.). (2001). A taxonomy for learning, teaching, and assessing: A revision of Bloom's taxonomy of educational objectives. New York: Longman.

Bendl, S. (2005). Reinterpretace kázně v současné škole. Pedagogická orientace, 15(2), 2-14.

Bradová, J. (2012). Ked' zasadací poriadok funguje alebo učitelsko-žiacké preferencie pri obsadzovaní priestoru školskej triedy. Studia paedagogica, 17(2), 71-92.

Carroll, J. B. (1963). A model of school learning. Teachers College Record, 64(8), 723-733.

Clarke, A. (2003). Situational analyses: Grounded theory mapping after the postmodern turn. Symbolic Interaction, 26(4), 553-576.

Clarke, A. (2005). Situational analysis: Grounded theory after the postmodern turn. Thousand Oaks: SAGE.

Cook-Sather, A. (2006). Sound, presence and power: „Student voice“ in educational research and reform. Curriculum Inquiry, 34(4), 359-390.

Cothran, D. J., \& Ennis, C. D. (1997). Students' and teachers' perception of conflict and power. Teaching and Teacher Education, 13(5), 541-553.

Creswell, J. W. (2014). Research design: Qualitative, quantitative, and mixed methods approaches. Thousand Oaks: SAGE.

Čejková, I. (2014). Nuda ve škole. Studia paedagogica, 19(3), 155-170.

ČŠI. (2016). Kritéria hodnocení podmínek, průběhu a výsledků vzdělávání. Praha: Česká školní inspekce.

Federičová, M., \& Münich, D. (2015). Srovnání žákovské obliby školy a matematiky pohledem mezinárodních šetření. Pedagogická orientace, 25(4), 557-582.

Fletcher, A. (2007). Student voice tip sheet. Washington: SoundOut. Dostupné z http://www. soundout.org/tips.html

Hargreaves, D. (1972). Interpersonal relations and education. London: Routledge and Kegan.

Harper, D. (2000). Students as change agents: The generation Y model. Olympia: Generation Y Organization.

Harvey, L., \& Green, D. (1993). Defining quality. Assessment \& Evaluation in Higher Education, 18(1), 9-34.

Hattie, J. (2003, říjen). Teachers make a difference: What is the research evidence? Příspěvek prezentován na ACER Research Conference, Melbourne, Austrálie. Dostupné z http:// research.acer.edu.au/research_conference_2003/4/ 
Hrabal, V., \& Pavelková, I. (2010). Jaký jsem učitel. Praha: Portál.

Charmaz, K. (2006). Constructing grounded theory: A practical guide through qualitative analysis. London: SAGE.

Chvál, M. (2013). Změna postojů českých žáků k matematice během školní docházky. Orbis scholae, 7(3), 49-71.

Chvál, M. (2018). Na naší škole nám záleží: Jak sledovat a hodnotit kvalitu školy. Praha: Portál.

Janík, T. (2009). Didaktické znalosti obsahu a jejich význam pro oborové didaktiky, tvorbu kurikula a učitelské vzdělávání. Brno: Paido.

Janík, T. (2007). Pedagogical content knowledge nebo didaktická znalost obsahu? Brno: Paido.

Janík, T. (2008). Metodologické problémy výzkumu didaktických znalostí obsahu. Brno: Paido.

Janík, T., Slavík, J., Mužík, V., Trna, J., Janko, T., Lokajíčková, V., \& Zlatníček, P. (2013). Kvalita (ve) vzdělávání: obsahově zaměrený př́stup ke zkoumání a zlepšování výuky. Brno: Masarykova univerzita.

Janíková, M., Vlčková, K., Doulík, P., Chvál, M., Janík, T., Jelemenská, P., ... Škoda, J. (2009). Výzkum výuky: tematické oblasti, výzkumné př́stupy a metody. Brno: Paido.

Kalenda, J. (2016). Prozatím nevyužitá šance: situační analýza v pedagogickém výzkumu. Pedagogická orientace, 26(3), 457-481.

Kubiatko, M., Mrázková, K., \& Janko, T. (2011). Postoje žáků 2. stupně základních škol k vyučovacímu předmětu zeměpis. Pedagogika, 61(3), 257-270.

Maňák, J., \& Janík, T. (2009). Výukové metody jako předmět výzkumu. In M. Janíková \& K. Vlčková, (Eds.), Výzkum výuky: tematické oblasti, výzkumné př́stupy a metody (s. 83-96). Brno: Paido.

Mortimore, P., Sammons, P., Stoll, L., Lewis, D., \& Ecob, R. (1989). A study of effective junior schools. International Journal of Educational Research, 13(7), 753-768.

Najvar, P., Najvarová, V., Janík, T., \& Šebestová, S. (2011). Videostudie v pedagogickém výzkumu. Brno: Paido.

Pavelková, I. (2013). Postoje žáků k českému jazyku a jejich percepce učiteli. Didaktické studie, 5(1), 27-45.

Průcha, J., Walterová, E., \& Mareš, J. (2009). Pedagogický slovník. Praha: Portál.

Race, P. (2007). The lecturer's toolkit: A practical guide to assessment, learning and teaching. London: Routledge.

Ramsden, P. (2003). Learning to teach in higher education. London: Routledge.

Rámcový vzdělávací program pro gymnázia (2007). Praha: VÚP.

Rodgers, C. (2006). Attending to student voice: The impact of descriptive feedback on learning and teaching. Curriculum Inquiry, 36(2), 209-237.

Rogers, A. L. (2005). Student voice: Bridges to learning. Seattle: University Washington.

Rudduck, J., \& Flutter, J. (2000). Pupil participation and pupil perspective: „Carving a new order of exprience“. Cambridge Journal of Education, 30(1), 75-89.

Rudduck, J., \& McIntyre, D. (2007). Improving learning through consulting pupils. London: Routledge.

Řiháček, T., \& Hytych, R. (2013). Metoda zakotvené teorie. In T. Řiháček, I. Čermák, \& R. Hytych (Eds.), Kvalitativní analýza textů: čtyři př́stupy (s. 44-74). Brno: Muni press. 
Scheerens, J. (2004, březen). Review of school and instructional effectiveness research. Příspěvek prezentován na EFA Global Monitoring Report to UNESCO. Dostupné z http://unesdoc. unesco.org/images/0014/001466/146695e.pdf

Shulman L. S. (1986). Those who understand: Knowledge growth in teaching. Educational Researcher, 15(2), 4-14.

Starý, K., Dvořák, D., Greger, D., \& Duschinská, K. (2012). Profesní rozvoj učitelů: podpora učitelů pro zlepšování výsledků žáků. Praha: Karolinum.

Starý, K., \& Chvál, M. (2009). Kvalita a efektivita výuky: metodologické př́istupy. In M. Janíková \& K. Vlčková, (Eds.) Výzkum výuky: tematické oblasti, výzkumné přístupy a metody (s. 63-81). Brno: Paido.

Straková, J. (2010). Postoje české společnosti ke vzdělávání a jejich vývoj v čase. Studia paedagogica, 15(2), 27-42.

Strauss, A., \& Corbin, J. (1999). Základy kvalitativního výzkumu. Postupy a techniky metody zakotvené teorie. Boskovice: Albert.

Šed'ová, K. (2011). Mocenské konstelace ve výukové komunikaci. Studia paedagogica, 16(1), 89-118.

Šed'ová K., Sucháček P., \& Majcík, M. (2015). Kdopak to mluví? Participace žáků ve výukové komunikaci na druhém stupni základní školy. Pedagogika, 65(2), 143-162.

Šed'ová, K., Švaříček, R., \& Šalamounová, Z. (2012). Komunikace ve školní třídě. Praha: Portál.

Šed'ová, K., Švaříček, R., Šalamounová, Z., \& Sedláček, M. (2016). Jak se učitelé učí: cestou profesního rozvoje k dialogickému vyučování. Brno: Masarykova univerzita.

Švaříček, R. (2011). Funkce učitelských otázek ve výukové komunikaci na druhém stupni základní školy. Studia paedagogica, 16(1), 9-46.

Švaříček, R. (2013). Sedm pravidel kognitivně nároční výuky. Komenský, 138(1), 11-17.

Švaříček, R., \& Čejková, I. (2016). Metaforický svět učení. In M. Strouhal \& S. Štech (Eds.), Vzdělání a dnešek (s. 124-145). Praha: Karolinum.

Švaříček, R., Šed’ová, K., Janík, T., Kaščák, O., Miková, M., Nedbálková, K., ... Zounek, J. (2007). Kvalitativní výzkum v pedagogických vědách: pravidla hry. Praha: Portál.

Trigwell, K., \& Prosser, M. (1996). Changing approaches to teaching: A relational perspective. Studies in Higher Education, 21(3), 275-284.

Vidláková, J. (2011). Hlas žáků jako součást jejich participace na životě školy (dizertační práce). Brno: Masarykova univerzita.

Winograd, K. (2002). The negotiative dimension of teaching: Teachers sharing power with the less powerful. Teaching and Teacher Education, 18(3), 343-362.

Woods, P. (2012). The divided school. London: Routledge.

Žák, V. (2008). Zjišt’ování parametrů kvality výuky fyziky. Pedagogika, 58(1), 61-72.

\section{Autorka}

Mgr. Ingrid Čejková, Masarykova univerzita, Filozofická fakulta, Ústav pedagogických věd, A. Nováka 1, 60200 Brno, e-mail: cejkova@phil.muni.cz 


\title{
Student teaching evaluation/assessment at grammar school
}

\begin{abstract}
The aim of the presented study is to find out how pupils of grammar school evaluate the teaching of individual lessons and subjects as well as whether pupil's assessment of teaching can have a driving force enabling pupils to influence the form of teaching towards its efficiency and quality. The design of the study is qualitative research. The examined phenomenon has been explored through observations of teaching and interviews with pupils and teachers of one high school class. Based on the analysis of the data obtained, it was found that pupils are able to evaluate the teaching from different points of view and take into account a whole range of teaching elements. The essential elements of the lessons that pupils observe are, for example: the characteristics and behavior of the teacher, the teacher's expertise, the didactic competence of the teacher and the related learning objectives, the teaching methods, the learning effects, etc. The whole pupil's assessment of teaching is a result of a comprehensive analysis of the individual elements of teaching, the synthesis of these elements and the formulation of the final opinion.
\end{abstract}

Keywords: grammar school, teaching evaluation/assessment, teaching efficiency, teaching quality, pupil voice, situational maps, mathematics, Czech language and literature

Chvál M. (2018). Na naší škole nám záleží. Praha: Portál.

Ředitelé i učitelé se starají o to, aby jejich škola byla dobrá, aby si z ní žáci co nejvíce odnesli a aby do ní chodili rádi nejen žáci a jejich rodiče, ale i učitelé. Důležité je, aby si spolu rozuměli v tom, oč usilují. To nejde bez občasného zastavení, ohlédnutí a nového pohledu dopředu. Jak je možné bavit se o kvalitě školy, když se pohledy všech zúčastněných mohou lišit? Ve školním roce 2015/2016 zveřejnila Česká školní inspekce kritéria, která nám pomáhají kvalitu školy pojmenovat a mohou se stát společným jazykem pro všechny zúčastněné. Na pozadí těchto kritérií, je v knize věnována pozornost jednotlivým oblastem práce školy, jejího vedení a učitelů. K př́íslušným tématům jsou voleny praktické ukázky a konkrétní návody pro vlastní sledování, vyhodnocování a řešení různých situací. Cílem knihy je nejen vybavit školu silnou argumentační oporou při kontrole externími orgány, ale zejména nabídnout témata pro společná zastavení, ohlédnutí a úvahu o dalším rozvoji konkrétní školy. Knihu ocení školští inspektoři, ředitelé škol a učitelé, ale i zapálení rodiče, jimž na chodu školy záleží nebo kteří uvažují o založení vlastní školy. 